\title{
THE APPROXIMATE FORMULA FOR LIFT DISTRIBUTION ON A RECTANGULAR AEROFOIL.
}

\author{
By K. Wada, Member.
}

\begin{abstract}
Assuming a very simple form of expression for the lift distribution along the span of a rectingular aerofoil, formulas for the transformation of aspect ratio and the wind tunnel boundary correction have been obtained which agree quite satisiactorily with experiments
\end{abstract}

\section{Introduction.}

An accurate knowledge of the lift distribution on an aerofoil is most essential in aeronautics from aerodynamical as well as from constructional standpoints. The problem involves an integral equation and its exact solution can hardly be expected tn its general form. The simplest case to consider is that of a rectangular aerofoil with constant angle of incidence and chord across the span. The problem as such has been attacked first by Betz $^{(1)}$ and afterwards by Fuchs, ${ }^{(2)}$ Trefftz, ${ }^{(3)}$ Glauert, ${ }^{(4)}$ Gates ${ }^{(5)}$ and others. The results obtained by them are in more of less complicated forms and are not convenient in the application to practical problems, such as, in obtaining the transformation formula of aspect ratio or the correction formula for the wind tunnel interference.

The present author has obtained a very convenient formula of the lift distribuiion for an aerofoil having constant angle of incidence and chord. Though it is only a formula of approximation the comparison of the results deduced therefrom with those obtained by the more elaborate methods or by experiments seems to suggest its merit as a good first approximation.

(1) Betz: "Beiträge zur Tragflügeltheorie mit besonderer Berücksichtigung des einfachen rechteckigen Flügels." Göttingen Dissertation, (1919).

(2) Fuchs: "Beiträge zur Prandtlschen Tragflügeltheorie," 'ZAMM' Bd. I, (1921) p. 106.

(3) Trefftz: "Prandtlsche Trageächen-und Propeller-Theorie." 'ZAMM' Bd. I (1921) p. 206.

(4) Glauert: "The Element of Aerofoil and Airscrew Theory' p. 137. (1926)

(5) Gates: “An Analysis of a Rectangular Monopane with Hinged Tips." ' $R$. and M.' No. 1175 (19:8). 


\section{The Fundamental Equation.}

An aerofoil is replaced by a bound line vortex and a system of trailing vortices in accordance with Prandtl's aerofoil theory. ${ }^{(1)}$

The flow at any section of an aerofoil differs from the flow which would occur round the section in two dimensional motion owing to the influence of the trailing vortex system. The trailing vortex system gives rise to an induced velocity at a point of the aerofoil. The induced velocity is normal to the span of the aerofoil and to the direction of the motion. It will be denoted by $w$ and will be assumed to be small in comparison with the velocity $V$ of the general stream of air. The effect of the induced velocity is then equivalent to a reduction of the angle of incidence at the point of the aerofoil by $w / V$.

The lift coefficient is generally a function of the effective angle of incidence. If $\alpha$ is the geometrical angle of incidence at a point of the aerofoil, the effective angle of incidence $\alpha_{e}$ is

$$
\alpha_{e}=\alpha-\frac{w}{V} .
$$

Therefore the lift coefficient $c_{a}$ of the aerofoil section at the point is

$$
c_{a}=f n\left(\alpha-\frac{w}{V}\right) \text {. }
$$

Expanding by Taylor's theorem and neglecting the terms of the higher power of $w / V$,

$$
c_{a}=c_{a \infty}-\frac{d c_{a \infty}}{d \alpha}-\frac{w}{V},
$$

where $c_{a \infty}$ denotes the lift coefficient of the aerofoil section in two dimensional flow or that corresponding to the geometrical angle of incidence $\alpha$. The theory of an aerofoil $^{(2)}$ in two dimensional flow has shown that $\frac{d c_{r_{\infty}}}{d \alpha}$ is approximately equal to $2 \pi$ for all practical aerofoil sections at small angle of incidence. Hence

$$
c_{a}=c_{a \infty}-2 \pi \frac{w}{V} .
$$

This is the fundamental equation connecting the lift coefficient and the induced velocity.

If $\Gamma$ and $\Gamma_{\infty}$ are the circulations round the aerofoil section at any point under consideration in the actual state and in the state of two dimensional motion respec-

(1) Prandtl : 'Tragflügeltheorie,' Göttingen Nachrichten, 1918 and 1919.

(2) Glauert, loc. cit. p. 86. 
tively and $t$ the chord of the aerofoil, then expression (2) can also be written

$$
\Gamma=\Gamma_{\infty}-\pi t w
$$

the relationship between the circulation and the lift coefficient being given from Kutta-Joukowski's equation ${ }^{(1)}$ as follows :

$$
\Gamma=\frac{1}{2} c_{a} V t
$$

\section{The Approximate Expression for Lift Distribution.}

It is assumed that the circulation $\Gamma$ at any point of aerofoil, which is naturally a function of co-ordinate $y$ along the span, (the origin being taken at the middle of the span) may be expressed as follows:

$$
\Gamma=\Gamma_{0}\left(1-\eta^{2}\right)^{m}
$$

where $\Gamma_{0}$ is the circulation round the aerofoil section at the middle of span, $\eta$ denotes. $y / b$, in which $b$ is the half-span of the aerofoil, and $m$ is a positive number.

With the assumed constancy of the chord and the geometrical angle of incidence of the aerofoil section over the span, $m$ may be considered to be a function of the aspect ratio only.

The approximate result obtained by $\mathrm{Fuchs}^{(2)}$ seems to suggest the following form, for $m$ :

$$
2 m=\frac{k \frac{\pi t}{b}}{1+k \frac{\pi t}{b}} .
$$

It has been found after trial that unity seems to be the most appropriate value for $k$. Hence

$$
2 m=\frac{\frac{\pi t}{b}}{1+\frac{\pi t}{b}} .
$$

It is evident at once that expression (5) satisfies conditions at the extreme cases. Namely, when the span of an aerofoil becomes very large, from (5) $m$ tends to zero or, from (4), the distribution of circulation is getting uniform along the span as may be expected. On the contrary, if the chord of an aerofoil is getting very large, the

(1) Fuchs and Hopf: 'Aerodynamik' (1922) p. 63.

(2) Fuchs, loc. cit. p. 113. 
expression (5) gives $\frac{1}{2}$ as the limiting value for $m$, which agrees with the result obtained by Betz. ${ }^{(1)}$

For intermediate cases the comparison is made in Fig. 1 between the results obtained from (4) and (5) and those by Fuchs ${ }^{(2)}$ and Trefftz, ${ }^{(3)}$ which have been obtained by more tedious methods. The agreement of the results is quite good and seems to be consistent with the view that the lift distribution may be expressed in a simple form as given by expression (4), at least within the limit of a good first approximation.

\section{Further Results derived.}

The lift of an elementary section of an aerofoil can be obtained from the circulation round it by Kutta-Joukowski's equation ${ }^{(4)}$

$$
d A=\rho V \Gamma d y,
$$

where $d A$ denotes the lift of the elementary aerofoil section. Then the total lift is obtained very simply by evaluating the integral

or

$$
\begin{aligned}
A & =\rho V b \int_{-1}^{1} \Gamma d \eta \\
& =2 \rho V b \Gamma_{0} \int_{0}^{1}\left(1-\eta^{2}\right)^{m} d \eta .
\end{aligned}
$$

The integral can be easily evaluated in terms of Gauss' $I$ function, namely

$$
A=\rho V b \Gamma_{0} \sqrt{\pi} \frac{\Pi(m)}{\Pi\left(m+\frac{1}{2}\right)},
$$

where $\Pi(a)$ denotes Gauss' $I I$ function.

The lift coefficient of the aerofoil is, therefore,

$$
c_{a}=\frac{\sqrt{\pi}}{2} \frac{\Pi(m)}{2 \Pi\left(m+\frac{1}{2}\right)} c_{a 0}
$$

where $c_{a o}$ is the lift coefficient of the aerofoil section at the middle of the span.

Betz $^{(6)}$ has given in his paper the calculated value of the ratio of the mean circulation $\Gamma_{m}$ over the aerofoil to the circulation round the middle section, namely the value of $\Gamma_{m} / \Gamma_{0}$ or, it is the same thing, of $c_{a} / c_{a 0}$. The value of the same ratio

\footnotetext{
(1) Betz, loc. cit.

(2) Fuchs, loc. cit.

(3) Trefftz, loc. cit.

(i) Fuchs and Hopf, loc. cit.

(5) Jahnke-Emde: 'Funktiontafeln mit Formeln und Kurven.' p. 28.

(6) Betz, loc. cit.
} 
has been calculated by means of formula $\left(6^{\prime}\right)$ and it is compared with that due to Betz in Table I. The numerical value of Gauss' $I I$ function can easily be obtained from any mathematical table. ${ }^{(1)}$

Table I. Value of $\Gamma_{m} / \Gamma_{0}$.

\begin{tabular}{|c|c|c|c||c|c|c|c|}
\hline $\boldsymbol{L}$ & $m$ & Betz & Wada & $L$ & $m$ & Betz & Wada \\
\cline { 2 - 7 } $\mathbf{1}$ & 0.400 & 0.820 & 0.817 & 4 & 0.250 & 0.876 & 0.875 \\
2 & 0.333 & 0.844 & 0.842 & 9 & 0.154 & 0.916 & 0.916 \\
\hline
\end{tabular}

The agreement is quite satisfactory.

The induced velocity $w_{0}$ at the middle section of the aerofoil can be determined by evaluating the integral ${ }^{(2)}$

$$
\begin{aligned}
w_{0} & =-\frac{1}{4 \pi b} \int_{-1}^{1} \frac{d \Gamma}{d \eta} \frac{d \eta}{\eta} \\
& =\frac{m \Gamma_{11}}{\pi b} \int_{-1}^{1}\left(1-\eta^{2}\right)^{m-1} d \eta \\
& =\frac{m \Gamma_{0}}{2 b \sqrt{\pi}}\left(m+\frac{1}{2}\right) \frac{\Pi(m)}{\Pi\left(m+\frac{1}{2}\right)} .
\end{aligned}
$$

From the fundamental equation $\left(2^{\prime}\right)$

$$
\Gamma_{0}=\Gamma_{\infty}-\pi t w_{0}
$$

whence

$$
\Gamma_{\infty}=\left\{1+\frac{t}{2 b}\left(m+\frac{1}{2}\right) \frac{\Pi(m)}{\Pi\left(m+\frac{1}{2}\right)}\right\} \Gamma_{0} .
$$

From $\left(6^{\prime}\right)$ and (8) the relation between $\Gamma_{\infty}$ and $\Gamma_{m}$ can be written in the following form :

or

$$
\begin{aligned}
& \Gamma_{\infty}=\left\{1+\frac{t}{2 b} \sqrt{\pi}\left(m+\frac{1}{2}\right) \frac{\Pi(m)}{\Pi\left(m+\frac{1}{2}\right)}\right\} \frac{2}{\sqrt{\pi}} \frac{\Pi\left(m+\frac{1}{2}\right)}{\Pi(m)} \Gamma_{m} \\
& c_{a \infty}=\left\{1+\frac{t}{2 b} \sqrt{\pi}\left(m+\frac{1}{2}\right) \frac{\Pi(m)}{\Pi\left(m+\frac{1}{2}\right)}\right\} \frac{2}{\sqrt{\pi}} \frac{\Pi\left(m+\frac{1}{2}\right)}{\Pi(m)} c_{a}
\end{aligned}
$$

(1) Jahnke-Emde. loc. cit. p. 31.

(2) Glauert, loc. cit. p. 134. 
The numerical value of $c_{a} / c_{a \infty}$ has been calculated by Betz ${ }^{(1)}$ and also it has been determined by $\left(9^{\prime}\right)$. Table II gives the comparison between the two results.

Table II. Value of $c_{a} / c_{a \infty}$.

\begin{tabular}{|c|c|c|c|c|}
\hline$L$ & $m$ & $\frac{2 b}{\pi t}$ & Betz & Wada \\
\hline 1 & 0.400 & 0.5 & 0.427 & 0.422 \\
2 & 0.333 & 1.0 & 0.588 & 0.582 \\
4 & 0.250 & 2.0 & 0.728 & 0.725 \\
9 & 0.154 & 4.5 & 0.847 & 0.845 \\
\hline
\end{tabular}

The fair agreement seems again provides confirmation of the assumption.

\section{The Transformation Formula for the Aspect Ratio.}

From the relation, which has been developed in the previous section, it is pos sible to establish the formula for the transformation of aspect ratio.

In formulas (9) and $\left(9^{\prime}\right)$ the left-side member is independent of the value of the aspect ratio, being a function of the geometrical angle of incidence only. Hence if the aspect ratio were reduced from $1 / \lambda_{1}$ to $1 / \lambda_{2}$, the relation of the lift coefficients at a given value of the geometrical angle of incidence can easily be obtained from $\left(9^{\prime}\right)$ in the following form :

$$
c_{a 2}=\frac{\frac{\Pi\left(m_{1}+\frac{1}{2}\right)}{I /\left(m_{1}\right)}+\sqrt{\pi} \lambda_{1}\left(m_{1}+\frac{1}{2}\right)}{\frac{\Pi\left(m_{2}+\frac{1}{2}\right)}{I I\left(m_{2}\right)}+\sqrt{\pi} \lambda_{2}\left(m_{2}+\frac{1}{2}\right)} c_{a 1},
$$

where $c_{a 1}$ and $c_{a 2}$ denote the lift coefficients corresponding to aspect ratios $1 / \lambda_{1}$ and $1 / \lambda_{2}$ respectively.

Having obtained the formula of the transformation of aspect ratio, it has been applied in transforming the result of experiment, which was carried out on an aerofoil of the aspect ratio unity, to the aspect ratio five. The transformed value is compared in Table III and Fig. 2 with the result of experiment made on the same aerofoil section but of the aspect ratio five. The numerical values have been taken from the result of experiments carried out at the Aerodynamical Researcin Institute. at Göttingen. ${ }^{(2)}$

(1) Betz, loc. cit.

(2) Ergebnisse der Aerodynamischen Versuchsanstalt zu Göttingen, I. Lieferung (1923), p. 53. 
The result is also compared with what has been obtained under the assumption of an elliptic distribution of lift. From Fig. 2 it may be seen that formula (10) gives much better agreement than that obtained with the usual assumption of an elliptic loading.

It may be remarked that the assumption of an elliptic loading gives rise to a constant induced velocity along the span of the aerofoil. Therefore the transformation of the aspect ratio can be effected by adjusting the angle of incidence for the same value of the lift coefficient. But in general the induced velocity is variable along the span and in the transformation the lift coefficient must be corrected for the same value of the geometrical angle of incidence.

Table III. Transformation of Aspect Ratio.

\begin{tabular}{|c|c|c|c|c|c|}
\hline \multicolumn{2}{|c|}{$\begin{array}{c}\text { Experimental result. } \\
\text { Aspect ratio } 5\end{array}$} & \multicolumn{2}{|c|}{$\begin{array}{c}\text { Experimental result. } \\
\text { Aspect ratio } 1\end{array}$} & \multirow{2}{*}{$\begin{array}{c}\quad c a \\
\text { transformed to } \\
\text { aspect ratio } 5 \\
\text { by }(10)\end{array}$} & \multirow{2}{*}{$\begin{array}{c}\alpha^{\circ} \\
\text { corrected for } \\
\text { aspect ratio } 5 \\
\text { by the } \\
\text { assumption of } \\
\text { elliptic loading }\end{array}$} \\
\hline $\begin{array}{c}\text { angle of } \\
\text { incidence } \alpha^{\circ}\end{array}$ & $c a$ & $\begin{array}{c}\text { ang'e of } \\
\text { incidence } \alpha^{\circ}\end{array}$ & $c a$ & & \\
\hline $\begin{array}{l}-8.9 \\
-6.0 \\
-4.5 \\
-3.1 \\
-1.6\end{array}$ & $\begin{array}{r}-0.274 \\
-0.078 \\
0.032 \\
0.137 \\
0.229\end{array}$ & $\begin{array}{l}-9.0 \\
-6.0 \\
-4.5 \\
-3.0 \\
-1.5\end{array}$ & $\begin{array}{r}-0.088 \\
-0.009 \\
0.036 \\
0.075 \\
0.122\end{array}$ & $\begin{array}{r}-0.185 \\
-0.019 \\
0.076 \\
0.158 \\
0.256\end{array}$ & $\begin{array}{l}-7.7 \\
-5.9 \\
-5.0 \\
-4.1 \\
-3.3\end{array}$ \\
\hline $\begin{array}{r}-0.1 \\
1.3 \\
2.8 \\
4.3 \\
5.7\end{array}$ & $\begin{array}{l}0.326 \\
0.432 \\
0.537 \\
0.635 \\
0.734\end{array}$ & $\begin{array}{r}0 \\
1.5 \\
3.0 \\
4.5 \\
6.0\end{array}$ & $\begin{array}{l}0.154 \\
0.203 \\
0.248 \\
0.295 \\
0.353\end{array}$ & $\begin{array}{l}0.324 \\
0.426 \\
0.521 \\
0.620 \\
0.742\end{array}$ & $\begin{array}{r}-2.2 \\
-1.5 \\
-0.8 \\
0.2 \\
0.9\end{array}$ \\
\hline $\begin{array}{r}8.7 \\
11.6 \\
14.6 \\
17.6\end{array}$ & $\begin{array}{l}0.939 \\
1.091 \\
1.154 \\
1.132\end{array}$ & $\begin{array}{r}9.0 \\
12.0 \\
15.0 \\
18.0\end{array}$ & $\begin{array}{l}0.450 \\
0.572 \\
0.688 \\
0.820\end{array}$ & $\begin{array}{l}0.946 \\
1.201 \\
1.446 \\
1.722\end{array}$ & $\begin{array}{l}2.4 \\
3.7 \\
5.0 \\
6.0\end{array}$ \\
\hline
\end{tabular}

\section{The Wind Tunnel Interference.}

The experiment in wind tunnel is naturally performed within a limited space of air flow. The effect of the boundary on the measured values of lift and drag experienced by an aerofoil is quite appreciable and it has been known that corrections must be applied to wind tunnel results before they can be applied to free air conditions. It is a usual procedure to assume an elliptic loading for the lift distribution of an aerofoil. It is the object of the present section to extend these results when the lift distribution is such as given by expression (4).

The problem shall be treated as two dimensional, assuming the trailing vortices 
were extending from plus to minus infinity.

Dealing with the case of the wind tunnel with a circular jet, or so called Göttingen type, the boundary condition to be satisfied is that the pressure is constant over the surface of the jet. It can easily be shown that, in such case, the system of the trailing vortices must be so compensated to give the circumferencial velocity at the boundary is zero. This is done by introducing for every trailing vortex an image vortex of equal strength and sign at the inverse point with respect to the circle corresponding to the boundary of the jet.

The induced downward velocity at $y_{1}$ (Fig. 3) due to the image vortices at the inverse points $y_{A}$ and $y_{B}$, corresponding to the trailing vortices at $\pm y$, is

$$
\begin{aligned}
d w_{y_{1}} & =\frac{1}{4 \pi} \frac{d \Gamma}{d y}\left(\frac{1}{y_{1}-y_{B}}-\frac{1}{y_{1}-y_{B}}\right) d y \\
& =-\frac{d \Gamma}{d y} \frac{y}{2 \pi R^{2}}\left(\frac{1}{1-\xi^{2}}\right) d y,
\end{aligned}
$$

where $\xi=y_{1} y / R^{2}$, denoting by $R$ the radius of the circle.

From the assumption for $\Gamma$ as given in (4) follows:

$$
d w_{y_{1}}=\frac{m b \Gamma_{0}}{\pi R^{2}} \frac{\eta^{2}\left(1-\eta^{2}\right)^{m-1}}{\left(1-\xi_{0}^{2} \eta^{2}\right)} d \eta
$$

where $\xi_{0}=y_{1} b \mid R^{2}$.

If $c_{a}$ denotes the lift coefficient corresponding to free air condition, it follows. from $\left(6^{\prime}\right)$ and (3)

$$
\Gamma_{0}=\frac{V t}{\sqrt{\pi}} \frac{\Pi\left(m+\frac{1}{2}\right)}{\Pi(m)} c_{a} .
$$

Hence

$$
d w_{y_{1}}=c_{a} \frac{m I\left(m+\frac{1}{2}\right)}{2 \sqrt{\pi} \Pi(m)} \frac{F V}{F_{0}} \frac{\boldsymbol{\eta}^{2}\left(1-\eta^{2}\right)^{m-1}}{\left(1-\xi_{0}^{2} \eta^{2}\right)} d \eta,
$$

where $F_{0}$ is the cross sectional area of the jet and $F$ is the total area of the aerofoil.

The total sum of the induced velocities at the point $y_{1}$ due to the images of the system of the trailing vortices corresponding to the assumed lift distribution may therefore be put in the form:

$$
w_{y_{1}}=c_{a} \frac{m}{2 \sqrt{\pi}} \frac{\Pi\left(m+\frac{1}{2}\right)}{I I(m)} \frac{F V}{F_{0}} \int_{0}^{1} \frac{\eta^{2}\left(1-\eta^{2}\right)^{m-1}}{\left(1-\xi_{0}^{2} \eta^{2}\right)} d \eta .
$$

Put for brevity 


$$
I=\int_{0}^{1} \frac{\eta^{2}\left(1-\eta^{2}\right)^{m-1}}{\left(1-\xi_{0}^{2} \eta^{2}\right)} d \eta
$$

The integrand becomes infinity at $\xi_{0}^{2} \eta^{2}=1$ or at $y^{\prime} y / R=1$ and it is to be understood that its principal value has been taken.

The integral $I$ can be evaluated as follows, expanding the denominator into an infinite series,

$$
\begin{aligned}
I & =\int_{0}^{1} \eta^{2}\left(1-\eta^{2}\right)^{m-1} \sum_{0}^{\infty} n \xi_{0}^{2 n} \eta^{2 n} d \eta \\
& =\frac{\Pi(m-1)}{2} \sum_{0}^{\infty} n \frac{\Pi\left(n+\frac{1}{2}\right)}{\Pi\left(m+n+\frac{1}{2}\right)} \xi_{0}^{2 n} \\
& =\frac{\sqrt{\pi}}{4} \frac{\Pi(m-1)}{\Pi\left(m+\frac{1}{2}\right)}\left\{1+\frac{3}{2 m+3} \xi_{0}^{2}+\frac{3 \cdot 5}{(2 m+3)(2 m+5)} \xi_{0}^{4}+\cdots \cdot\right.
\end{aligned}
$$

On substitution into (12) the induced velocity can be put

$$
\begin{aligned}
w_{y_{1}} & =c_{a} \frac{F V}{8 F_{0}}\left\{1+\sum_{1}^{\infty}{ }^{n} \frac{(2 n+1)(2 n-1) \ldots 5.3}{(2 m+2 n+1)(2 m+2 n-1) \ldots(2 m+5)(2 m+3)^{2}} \xi_{0}^{2 n}\right\}, \\
\text { or } \quad & =c_{a} \frac{F V}{8 F_{0}}\left\{1+\sum_{1}^{\infty}{ }^{n} p_{n} \xi_{0}^{2 n}\right\},
\end{aligned}
$$

ebbreviating the notation by writing

$$
p_{n}=\frac{(2 n+1)(2 n-1) \ldots 5.3}{(2 m+2 n+1)(2 m+2 n-1) \ldots(2 m+5)(2 m+3)} .
$$

The effect of the induced velocity due to the boundary may be considered to be aquivalent to a reduction of the effective angle of incidence at the point by $\Delta \alpha$, which is given by

$$
\Delta \alpha=-\frac{w_{\eta_{1}}}{V}=-\frac{c_{a} F}{8 F_{0}}\left(1+\sum_{1}^{\infty}{ }^{n} p_{n} \xi_{0}^{2 n}\right)
$$

Let $c_{a y_{1}}$ and $c_{a y_{1}}^{b}$ be the lift coefficients of the aerofoil section at $y_{1}$ corresponding to free and limited conditions of air flow. Then $c_{a y_{1}}^{b}$, obviously a function of the effective angle of incidence at the point, may be expressed

But from (4) and (8)

$$
c_{a y_{1}}^{b}=c_{a y_{1}}+\frac{d c_{a y_{1}}}{d \alpha} \Delta \alpha
$$

$$
\frac{d c_{m \eta_{1}}}{d \alpha}=\frac{2 \pi}{1+\frac{t}{2 b} \sqrt{\pi} \frac{\Pi(m)}{\Pi\left(m-\frac{1}{2}\right)}}\left(1-\eta_{1}^{2}\right)^{m} .
$$


On substitution into (16) the following relation is established:

$$
c_{a y_{1}}^{\prime \prime}=c_{a y_{1}}-\frac{2 \pi}{1+\frac{t}{2 b} \sqrt{\pi} \frac{I /(m)}{I I\left(m-\frac{1}{2}\right)}} \frac{F}{S F_{0}}\left(1-\eta_{1}^{\frac{2}{1}}\right)^{m}\left(1+\sum_{1}^{\infty} p_{n} \varepsilon_{0}^{2 n}\right) c_{a} .
$$

The total lift coefficient $c_{a}^{b}$ or the lift coefficient of the aerofoil within the limited air flow can be expressed:

$$
\begin{aligned}
c_{a}^{b} & =\int_{0}^{1} c_{a y_{1}}^{b} d \eta \\
& =c_{a}\left\{1-\frac{2 \pi}{1+\frac{t}{2 b} \sqrt{\pi} \frac{\Pi(m)}{\Pi\left(m-\frac{1}{2}\right)}} \frac{F}{8 F_{0}} \int_{0}^{1}\left(1-\eta^{2}\right)^{m}\left(1+\sum_{1}^{\infty}{ }^{n} p_{n} \zeta^{4 n} \eta^{2 n}\right) d \eta\right\} \\
& =c_{a}\left[1-\frac{2 \pi I I(m)}{1+\frac{t}{2 b} \sqrt{\pi} \frac{\Pi(m)}{\Pi\left(m-\frac{1}{2}\right)}} \frac{F}{8 F_{0}}\left\{\frac{\sqrt{\pi}}{2 \Pi\left(m+\frac{1}{2}\right)}+\sum_{1}^{\infty} \frac{p_{n}}{2} \frac{\Pi\left(n-\frac{1}{2}\right)}{\Pi\left(m+n+\frac{1}{2}\right)} \zeta^{4 n}\right\}\right]
\end{aligned}
$$

where $\zeta=b / R$ or $\xi_{0}=y_{1} b / R^{2}=\eta \zeta^{2}$.

But

$$
\begin{aligned}
& \sum_{1}^{\infty}{ }^{n} p_{n} \zeta^{4 n} \frac{\Pi(m) \Pi\left(n-\frac{1}{2}\right)}{2 \Pi\left(m+n+\frac{1}{2}\right)} \\
& \quad=\frac{\sqrt{\pi} \Pi(m)}{2 \Pi\left(m+\frac{1}{2}\right)} \frac{3}{(2 m+3)^{2}}\left\{1+\frac{3.5}{(2 m+5)^{2}} \zeta^{4}+\frac{3^{2} .5 .7}{(2 m+5)^{2}(2 m+7)^{2}} \zeta^{3}+\ldots\right\}
\end{aligned}
$$

Hence from (19)

$$
\boldsymbol{c}_{a}=\frac{\boldsymbol{c}_{a}^{b}}{1-\frac{\pi F}{4 F_{0}} \frac{\phi(\zeta)}{\frac{2}{\sqrt{\pi}} \frac{\Pi\left(m+\frac{1}{2}\right)}{\Pi(m)}+\frac{t}{b}\left(m+\frac{1}{2}\right)}},
$$

where $\phi(\zeta)$ denotes the following abbreviation

$$
\phi(\zeta)=1+\frac{3}{(2 m+3)^{2}} \zeta^{4}+\frac{3^{2} .5}{(2 m+3)^{2}(2 m+5)^{2}} \zeta^{8}+\frac{3^{3} .5 .7}{(2 m+3)^{2}(2 m+5)^{2}(2 m+7)^{2}} \zeta^{12}+\ldots
$$

Hence in order to convert the experimental result of a circular jet wind tunnel 
to free air condition the former result must be multiplied by a numerical constant as determined from (20).

\section{Comparison with Experimental Result.}

In order to verify the result established in the previous section an experiment has been made under very large diameter-span ratio $(b / R)$.

The test was carried out in the 1.5-meter wind tunnel of Aeronautical Research Institute, Tokyo Imperial University.

The aerofoil tested was Göttingen 420 section and of the following dimensions:

$\begin{array}{lc}\text { Span } & 143.3 \mathrm{~cm} . \\ \text { Chord } & 30.0 \mathrm{~cm} . \\ b / R & 0.956\end{array}$

It should be noted that the span is abnormally large compared with the diameter of the wind tunnel.

The lift coefficient $c_{a}^{b}$ as determined from the test is tabulated in the second column of Table IV and in Fig. 4. The values reduced to free air condition by means of the correction formnla (20) are "given in the third column of Table IV and in Fig. 4.

The result is compared in Fig. 4 with that obtained at Göttingen ${ }^{(2)}$, which has been deduced from the test performed with low value of span-diameter ratio, namely, $b / R=0.44$. The agreement is quite satisfactory to justify the assumption (4).

In Fig. 4 is also shown the lift coefficient as deduced from the experiment under the assumption of an elliptic loading. It will be seen that the assumption seems to fail in such an extreme case.

In conclusion the writer wishes to acknowledge his indebtedness to his assistants Mr. K. Toyoda and Mr. T. Fukui for their labour in preparing experiments and calculations.

Table IV.

\begin{tabular}{|c|c|c|c|c|c|c|c|c|c|c|c|c|c|c|}
\hline$\alpha^{0}$ & -9 & -6 & -3 & 0 & 3 & 6 & 8 & 10 & 12 & 14 & 16 & 18 & 20 & $\frac{22}{20}$ \\
\hline$c_{n}^{b}$ & .001 & .179 & .357 & .529 & .702 & .859 & .968 & 1.069 & 1.143 & 1.182 & 1.231 & 1.266 & 1.281 & $\frac{1.272}{1.25}$ \\
\hline $\boldsymbol{c}_{n}$ & .002 & .215 & .429 & .635 & .843 & 1.031 & 1.162 & 1.281 & 1.372 & 1.420 & 1.478 & 1.519 & 1.541 & 1.528 \\
\hline
\end{tabular}

The Wind Tunnel Department,

The Aeronautical Research Institute, Tokyo Imperial University.

October 1931.

\footnotetext{
(1) Report of the Aeronautical Research Institute, Tokyo Imperial University, Vol. V, No. 66.
}

(2) Göttingen Frgebnisse. loc. cit. p. 96. 
Fig. 1
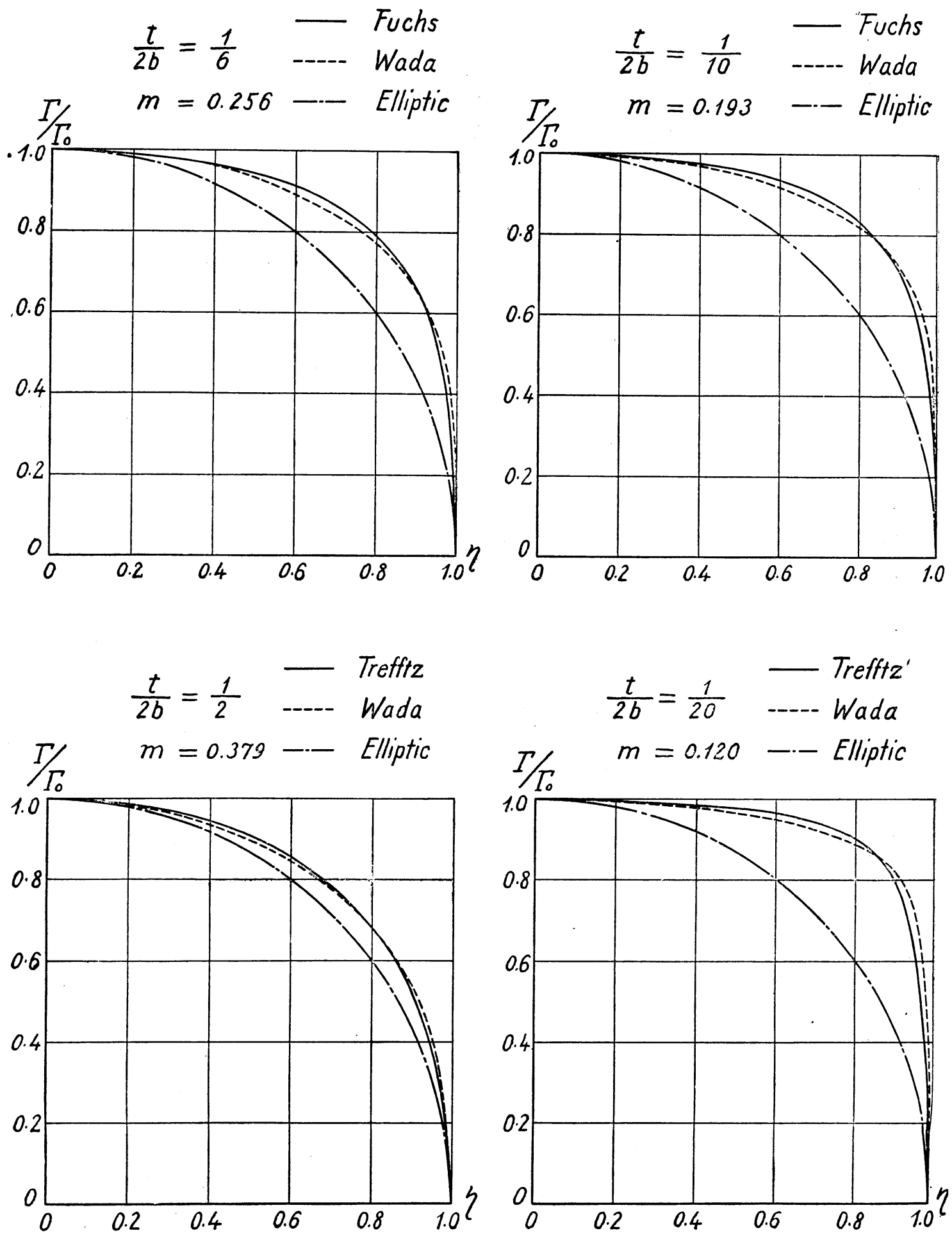
Fig. 2

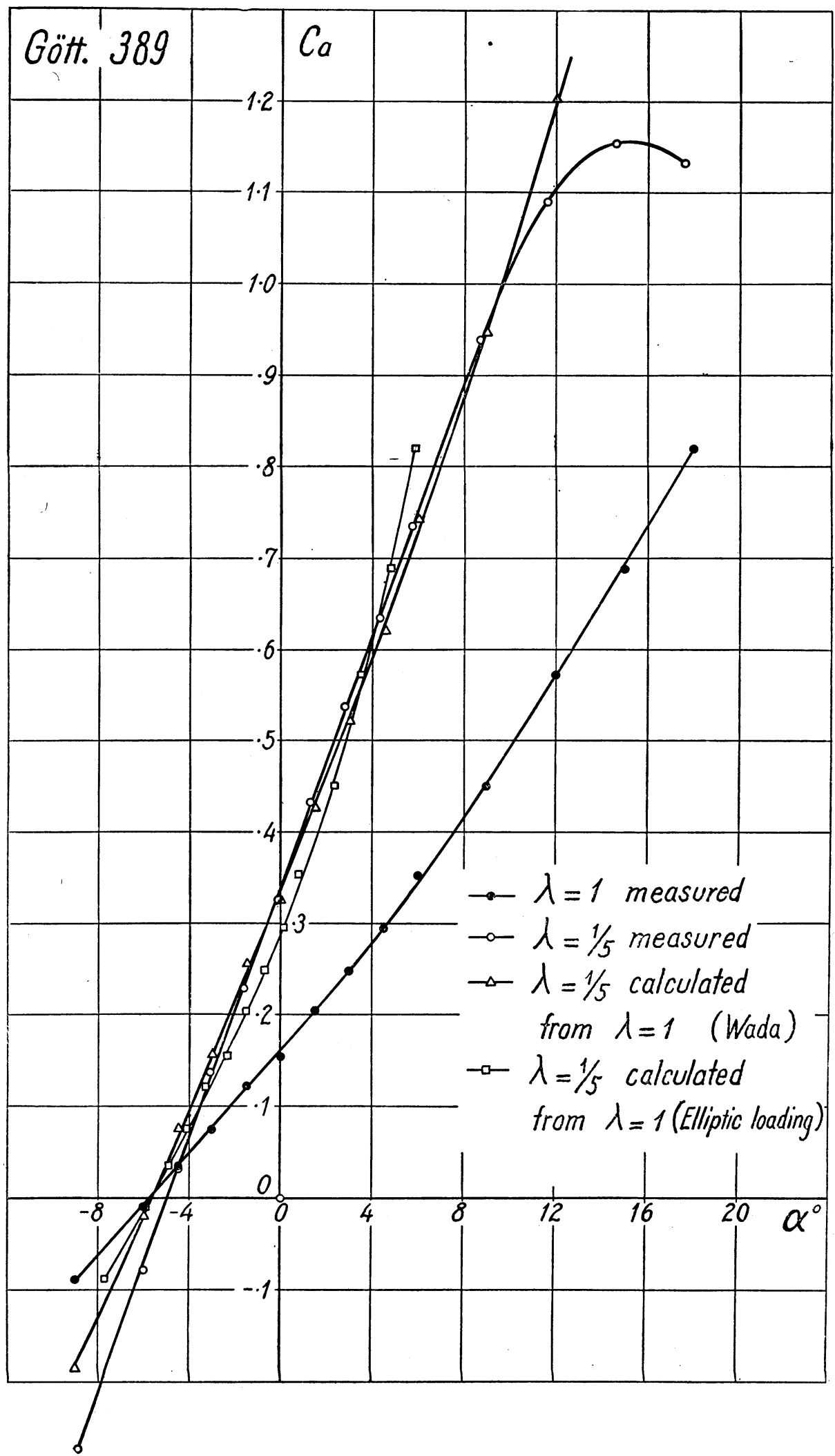


Fig. 3

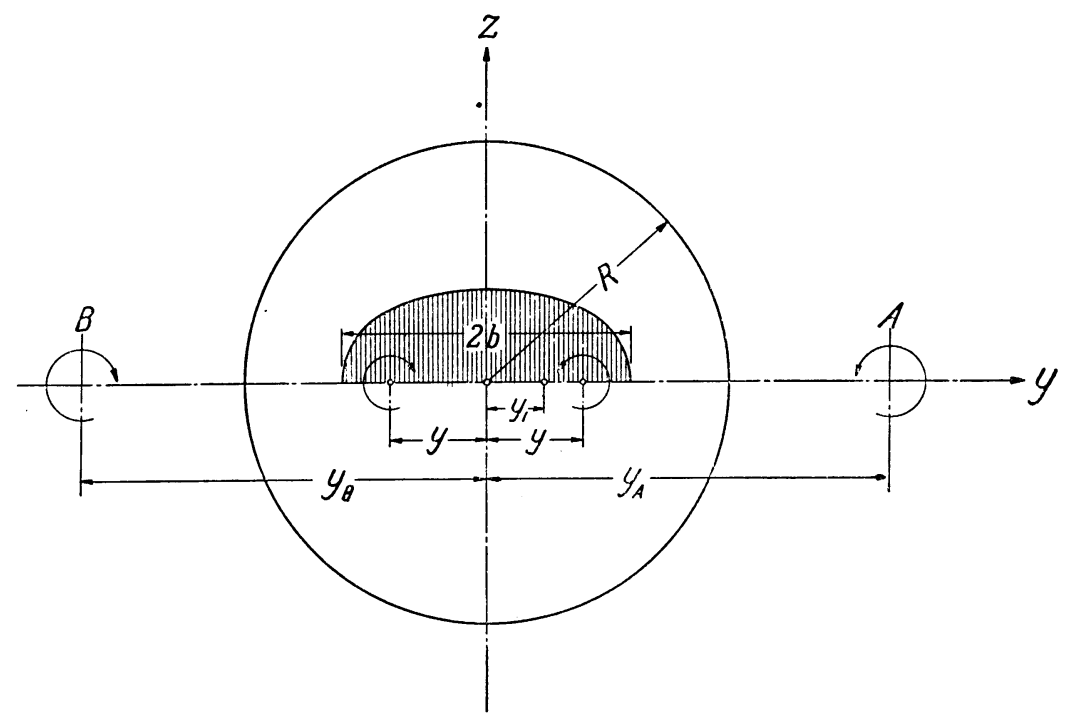

Fig. 4

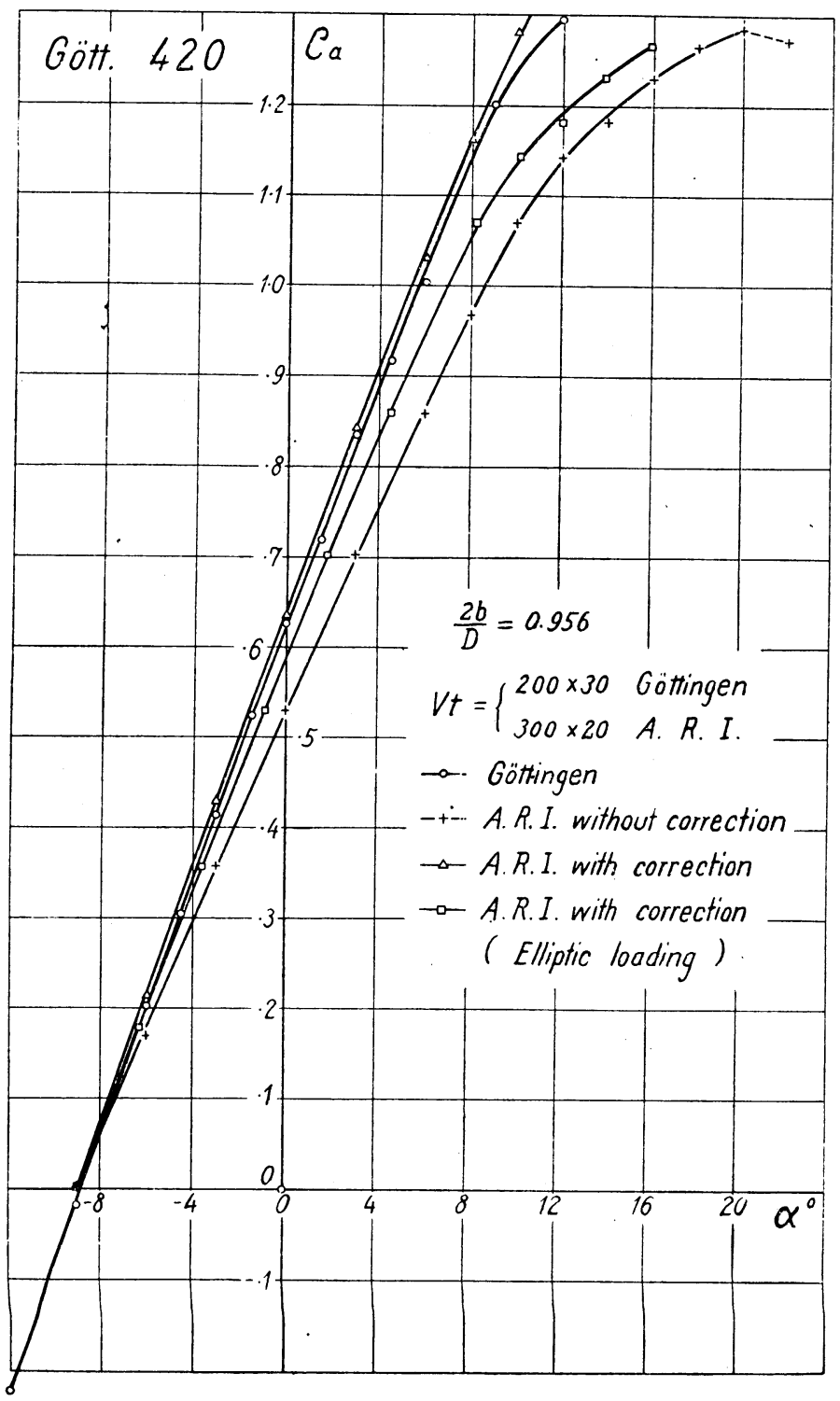




\section{討 論}

○會長代理（藤島範平君）唯今厄御講滨に對して御質問又は御意見のある方は御述べを願ひます。 ○山本武藏君 實驗に用ひた span と wind tunnel の dia. との ratio“が 0.956 であるとします と. trailing vortex は外に牛分位出はしませんか。

○和田小六君 出ません。

○山本武藏君 spanの中央部にて induced velocity w があるとすると、それは vortex の centre から遠い所での流體運動の䈆めである事勿論であるが、此 induced velocity 生ずる流體運動中其牛 分近くが風洞の外まで出て居る樣に思ひますが。

○和田小六君 流れの境界に於て pressure が一定であると云ふ條件で boundary 自身の形は adjustable でありますが、外に出るとは考へられないと思ひます。

○山本武藏君 一寸考へると自由にあるものと constrained flow の狀態にあるるのを考へて見る と其間に非常の差が起るべきが當然の樣ですが、いかがですか。

○和田小宍君 其 effect が郎ち境界修正となりますので、結果から見ると (4) 式の方が從來の椅 圓型分布より良いと思はれます。

○會長代理(藤島範平君） 他に別段御質問なくば私から一言御禮を申述へさせて戴きます。和田 博士は從來よりの正員でありますが、實は先般造船協會の定款を改正しまして航空を本會の目的の一 つに加へて、造船造機と並べて目的としました。從來からも航空關係の御方几御講演を願ひましたが。 早近な例を申す栐ですが恰も借家で講演される樣な狀態でありましたが、今後は自邸で講演される㮏 な譯でありまして、本講演は定款改正以來其意味での最初の講演でありまして、其點に於て有意義の ものと思ひます。此後益々航空關係の御發表あらん事を願ひます。

和田君の此の有益なる論文を御發表下さつた事に對しまして、諸君と共に拍手して、感謝の意を表 し度いと思ひます。(一同拍手) 